\title{
Restoring the Stolen Heritage in the New Land in Alex Haley's Roots
}

\author{
S.Hepsiba
}

\begin{abstract}
History has been handed down from generation to generation for time unknown through various sources before printing came to existence. Recording and passing of the events and the life is what helped and helps to retain the culture and tradition. Alex Haley's Roots is his attempt to retain the culture and tradition of his great great grandfather father, who was brought to America during $18^{\text {th }}$ century slave trading and pass the rich heritage that he had heard and researched. The story begins with the birth of Kunta and his captivity and his life at America, and then travels through the lives of generation till the time of the author's birth who traces his ancestry and decides to write a book on it. It is not the painful history of a family but of a man who was adamant not to lose his identity in the new land.
\end{abstract}

\section{Key words: Culture, Heritage, Roots}

\section{INTRODUCTION}

$\mathrm{H}$ istory has been handed down from generation to generation for time unknown through various sources before printing came to existence. In the oral tradition people of great valor and character were narrated to the younger generation through stories, songs, and enactment during festivals. In the history of any culture or nation we can trace back to the age old tradition and custom through this orally shared information. Recording of the events and the life is what helped and helps to retain the culture and tradition. Alex Haley's Roots is his attempt to retain the culture and tradition of his great great grandfather father, who was brought to America during $18^{\text {th }}$ century slave trading and pass the rich heritage that he had heard and researched.Though it has been questioned to be unauthentic and failed to prove its credit as a work of history it helped many to understand the rich heritage behind every Afro-American's.

Isabel Wilkerson, a historian and Pulitzer Prize winning author in his opinion shared to BuzzFeed states that "there may be questions about aspects of the research, but it was a turning point in America's relationship to its original sin, and it opened the way for most every work that followed that explores the effects of enslavement on America. It broke the silence on the unspeakable." Alex Haley himself being befuddled with a lot of criticism received to prove the authenticity of his history called his work a 'Faction' fusion of facts and fiction. He has brilliantly knitted the information gathered through his decade's hard work to present a wonderful legacy started with Kuta Kinte son of Omoro Kinte in the new land.

\section{ROOTS}

Revised Manuscript Received on December 20, 2019.

S. Hepsiba*,Department of English ,Kalasalingam Academy of Research and Education,Srivilliputhur,India. Email: hepsibamanick@gmail.com
'Roots' meaning the beginning discusses the beginning of the Afro-American and the terrible past that opened to the way for the life, especially the slavery system. It records every physical and mental suffering of the people who brought to America as slaves. As the title goes the story begins with the birth of Kunta Kinte and he being brought to America as a slave and life thereafter till Alex Haley, his sixth generation grandson and the author of the book, who went in search of his history and recorded them.

\section{A.Authors Heredity}

Alex from his young age listened to the story of his ancestors' home and his great grandfather Kunta Kinte, who was brought to America through his grandmother Bertha many a times which was passed down through every generation people. His inspiration for "Roots" came to him at London's British Museum in 1964 where he was struck by the story of the Rosetta Stone, the multi-lingual slab that helped researchers crack the code of Egyptian hieroglyphics, opening a new window on a "lost" world. Intrigued he set out his journey to trace his history that he has been grown listening to. He set out a decade-long journey across America and Europe, visiting nearly 50 libraries and archives and finally found the place of his great grandfather Kunta Kinte.

"Yeah, boy, dat African say his name was "Kintay'!...He say de guitar a 'ko," de river "Kamby Bolongo," an' he was chopping' wood to make his self a drum when dey cotched 'im! " Soon after, I went to the National Archives in Washington, D. C. "

\section{KUNTA KINTE}

\section{A.Kunta Kinte's Life In Africa}

Kunta Kinte was the first born son Omoro Kinte, a member of the old and highly esteemed Kinte family. Kunta was brought up learning the customs and traditions of Mandinka clan, and to match up the credit every Mandinka warrior beholds. Throughout his childhood, Kunta was taught to avoid and fear the "toubob," (slave traders) who was prevalently believed to sell the Africans to the white cannibals who live across ocean. Despite the warnings and the protection Kunta was captured and brought to America.

\section{B.Kunta Kinte's Life As Slave}

Kunta couldn't accept himself being enslaved and tries to escape. During his fourth attempt he was captured and had one of his foot cut down below the knee. Later he was bought by John Waller's brother William Waller, a physician by profession. In his place Kunta is being taken care of by Bell, William's cook. 
After a long time they decide to get married. They beget a baby girl and name her "Kizzy," which means "you stay put" in Mandinka after Bell's previous encounter with her babies being taken away from her. Dr. Waller assigns Kunta with driving him on his calls, through which he comes to know the news of the outside world.

\section{Passing Heritage To The Children}

Kunta though succumbed to his situation, he persists in keeping alive his dream of freedom and his pride in his African heritage. He passes on his knowledge and passion to his daughter Kizzy. Kizzy being a smart girl learns quickly about her father's African heritage and many Mandinka words. Unfortunately Kizzy is sold to Tom Lea as punishment for helping another slave to escape. Lea rapes Kizzy repeatedly and she begets a son and name him George. Kizzy devotes her life in bringing up George and passes on her father's knowledge and passion for freedom and Africa. George as a grown up inherits the characteristics of his mother and father. He excels himself in cockfighting like his father so that he can make more money easily and buy his family freedom.

Unexpectedly Lea loses all his fortune and sell George to an Englishman to save his family and promises Chicken George his freedom upon his return. Years later, Chicken George returns and earns his freedom but Kizzy is no more, so decides to be with his other family members. After the Civil war the family settles at Tennessee.

\section{D.Haleys Search For His Root}

But the family heritage and stories of Kunta is taught to the children until Haley recounts and goes in search of his family's story of "the African Kin-tay" who called a guitar a "ko" and the river "Kamby Bolongo."

In an era when most African Americans assumed it was impossible to track down proof of their ancestor's origins, which had been swept away by more than a century of slavery and racial persecution, Haley's doggedness led to remarkable results. People who are migrated to a new place willingly or unwillingly always find a part of themselves longing for their motherland and they try to keep a part of their custom or tradition alive at their new land. As a slave in America, in the land of the 'toubob' finds it very hard to see the life as normal as it was in his homeland Juffure and the African slaves too though accepted to live their life as slaves followed the similar custom as the people of his village.

\section{E. Restoring Heritage}

Haley helped the blacks and the world to see the rich heritage of his ancestor's land and presented a vivid portrayal of African people's culture and Life. Nancy L. Arnez in her article claims that "Approximately one-fifth of the book is dedicated to the cultural history of the African people...... Significantly the story is views primarily through the eyes of Kunta Kinte, one of Haley's ancestors. In this way Haley enables the reader to experience what the rains, hunger, depopulation, love, learning and responsibly meant to the Mandinkas."
Barbara Maranzani in her 'Remembering Roots' produced a statistical impact caused by Roots in the life of the Afro-Americans. Many people tried the methods used by Haley to trace back the history of their family too. It also affected the way of naming the children. It made a positive reaction and pride which increased the number of children receiving ethnic and African-inspired names.

\section{CONCLUSION}

Fact or Fiction Haley wanted to record the history of his family and he had succeeded in it. Despite the criticism received it is a true tale of existence of a culture against all intricacy. Kunta though being captured and tortured he has made his roots and his culture exist. It was nurtured for generations and enjoyed the triumph of existence and restoration through Haley. As Alex Haley once stated"Roots is not just a saga of my family. It is the symbolic saga of a people."

\section{REFERENCES}

1. Arnez, Nancy L. "From His Story to Our Story: A Review of 'Roots." The Journal of Negro Education, vol. 46, no. 3, 1977, pp. 367-372. JSTOR, www.jstor.org/stable/2966780.

2. From Freedom to Freedom African Roots in American Soil. New York: Random House, 1977.289-311.Print.

3. Haley, Alex. ROOTS, Random House, 1994

4. "Roots: The Saga of an American Family - Summary" Society and Self, Critical Representations in Literature_Ed. David Peck. eNotes.com, Inc. $1997.15 \quad$ May, 2019 <http://www.enotes.com/topics/roots\#summary-summary-summary-th e-work>

5. MARANZANI, B. (2019). Remembering “Roots". [online] HISTORY. Available at: https://www.history.com/news/remembering-roots [Accessed 1 May 2019].

6. Theroot.com. (2019). [online] Available at:

7. https://www.theroot.com/alex-haley-roots-and-the-enduring-power-of-b lack-myth-1790854799 [Accessed 29 May 2019].

\section{AUTHORS PROFILE}

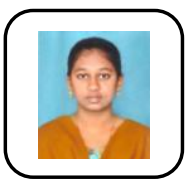

Mrs. S.Hepsiba M.A., M.Phil is a Assistant Professor in Dept. of English,Kalasalingam Academy of Research and Education, Deemed to be University, Krishnankoil, Tamilnadu. Graduating from Nallamuthu Gounder Mahalingam College,Pollachi. She did her M.Phil in N.G.M College under the guidance of Dr. Suja Mathew who had been an inspiration for her research accomplishment on Canadian writer, Yann Martel. She has presented and published many articles in literature, has attended many Workshops and Training Programmes to her credit. She has a passion for teaching literature to young minds in the pursuit of knowledge. 